\title{
Biology and Philosophy. VII. Sokrates, the Demigod
}

\author{
Juan S. Gómez-Jeria
}

\begin{abstract}
I use the cylinder-ladder model presented in the previous paper of this series to present and defend the thesis that Sokrates was placed in a step much higher than those that were occupied by almost all mortals regarding the degree of perception of reality and that he could perfectly be situated in the category of 'demigod' as defined in this paper. Plato's Apology is considered the most probable and unique Sokratic-like text. Furthermore, I claim that Sokrates knew that he was (relatively) wiser than those around him due to its higher position on the cylinder-ladder. This last statement opens new questions about the response of the Pythia. Sokrates was clear that his discourse would be understood by his listeners accordingly to the place they occupied in the cylinder-ladder model. This is the reason because, after Sokrates death, so many different Socratic schools appeared. Finally, I firmly hold the idea that one day we will discover that our knowledge of Sokrates has not grown one iota since his death. Sokrates seems to be the first known Western stonecutter/ stonemason whose raw material is men.
\end{abstract}

Index Terms-Apology, Cynicism, Delphi Oracle, Demigods, Pythia, Plato, Socrates, Sokrates, Socratic Schools, Xenophon.

Few men think; yet all have opinions (George Berkeley).

\section{INTRODUCTION}

The category of Demigods comprises Homo sapiens attaining divine status after their death (Julius Caesar [1], some Roman Emperors ${ }^{[2]}$, Perseus (? $\left.{ }^{[3]}\right)$, Homo sapiens that were believed to have as progenitors a human and a god (or goddess, Achilles, Aeneas, Asclepius, Harmonia, Heracles, Orpheus, Perseus (? ${ }^{[3]}$, Theseus, Romulus and Remus, Arjuna, Hanuman, Sæmingr, Gilgamesh, Semiramis, etc. ${ }^{[4-6]}$ ) or a minor deity (Iacchus, Marduk at the beginning, Rushou, Artesia, Silvanus, Adonis, Echo, etc. $\left.{ }^{[4,}{ }^{7]}\right)$. The most degenerate and repellent current example of the first group corresponds to the cult of personality, inherent in the practice of Marxism. I think that a fourth category of demigods should be defined, which should include those individuals who demonstrated that their degree of perception of reality is or was much greater than that of the rest of the Homo sapiens. I think of examples such as Buddha and Yeshua.

Here I will use the cylinder-ladder model presented in the previous article of this series to support the thesis that Sokrates was located in steps much higher than those that occupy almost all mortals and that he could perfectly situated in the fourth category defined above.

\section{WHO WAS SOKRATES?}

Already for his contemporaries Sokrates was an enigma.

Juan S. Gómez-Jeria, Faculty of Sciences, University of Chile, Santiago, RM, Chile
His diverse pupils, though proclaiming themselves similarly faithful, presented opposing images of him. And in each of them, legend and history are probably mixed. Some well-known biographic details follow. There is a certain possibility that some facts are not exactly as they are told, even that some are just gossip, but that is not important in this context.

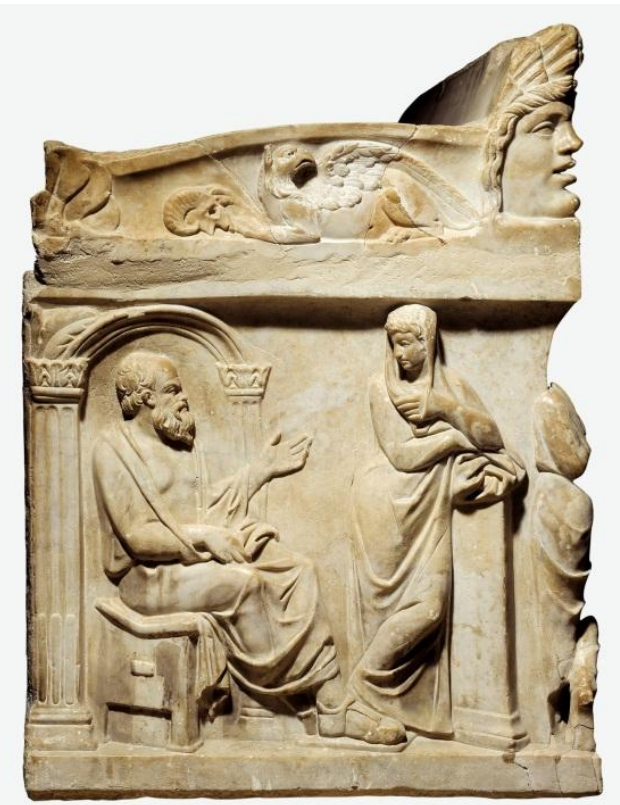

Sokrates (Roman sarcophagus, Louvre Museum).

Diogenes Laërtius stated Sokrates birth date was "the sixth day of Thargelion, the day when the Athenians purify the city". His date of birth is within the period of years ranging 470 to $469 \mathrm{BCE}$ or within a range 469 to $468 \mathrm{BCE}$ (corresponding to the fourth year of the 77th Olympiad). Sokrates was born as a man of the deme of Alopeke, near Athens $[\underline{8}, \underline{9}$. His father was Sophroniscus, a sculptor or stonecutter. His mother was a midwife named Phaenarete ${ }^{[10]}$. It was reported about him that when he was a boy he did not lead a good life and was not disciplined ${ }^{[11]}$. At first, it is said, he always disobeyed his father, and every time his father ordered to him to bring their working tools somewhere, he gave no heed to his order and ran about wherever he liked ${ }^{[11]}$. At some point toward the end of his adolescence (about 17 years old), Sokrates made an encounter that changed his life, orienting him toward philosophy: he became a pupil of Archelaus, the writer on nature, of whom Aristoxenus says he also became the beloved ${ }^{[11]}$. Sokrates did not refuse the intercourse and the company with Archelaus, remaining with him many years ${ }^{[11]}$. In his 50s Sokrates married Xanthippe, who is especially remembered for having an undesirable temperament. She bore for him three sons, Lamprocles, Sophroniscus and Menexenus; though Aristotle claimed that the latter two were his sons by another (presumably earlier) 
wife, Myrto, daughter of Lysimachus ${ }^{[10]}$. These women engaged in battle with one another, and whenever they paused, they attacked Sokrates, because he never prevented them from fighting but laughed when he saw them fighting with one another and with him. It is said that in his relationships Sokrates was sometimes quarrelsome, harsh and outrageous ${ }^{[11]}$. Sokrates is likely to have been trained as a stonemason. Aristoxenus says that he lent money in usury; and that he collected the interest and principal together, and then, when he had got the interest, he lent it out again ${ }^{[12]}$. Sokrates fulfilled the role of hoplite, participating in the Peloponnesian War. In the Apology, Sokrates states he was active for Athens in the battles of Amphipolis, Delium [13], and Potidaea ${ }^{[10]}$. During $406 \mathrm{BCE}$, he participated as a member of the Boule. His tribe the Antiochis held the Prytany on the day it was debated what fate should befall the generals of the Battle of Arginusae, who abandoned the slain and the survivors of foundered ships to pursue the defeated Spartan navy. The generals were seen by some to have failed to uphold the most basic of duties, and the people decided upon capital punishment. However, when the prytany responded by refusing to vote on the issue, the people reacted with threats of death directed at the prytany itself. They relented, at which point Sokrates alone as epistates blocked the vote, which had been proposed by Callixeinus. The reason he gave was that 'in no case would he act except in accordance with the law'. One of the generals executed was Pericles Junior, son of Pericles by Aspasia of Miletus ${ }^{[10]}$. Plato's Apology describes how Sokrates and four others were summoned to the Tholos, and told by representatives of the oligarchy of the Thirty (the oligarchy began ruling in $404 \mathrm{BCE}$ ) to go to Salamis, and from there, to return to them with Leon the Salaminian. He was to be brought back to be subsequently executed. However, Sokrates returned home and did not go to Salamis as he was expected to. Sokrates appears to have been a critic of democracy. Claiming loyalty to his city, Sokrates clashed with the current course of Athenian politics and society. He praised Sparta, archrival to Athens, directly and indirectly in various dialogues ${ }^{[10]}$. One of Sokrates' purported offenses to the city was his position as a social and moral critic. Rather than upholding a status quo and accepting the development of what he perceived as immorality within his region, Sokrates questioned the collective notion of "might makes right" that he felt was common in Greece during this period. Plato refers to Sokrates as the "gadfly" of the state, insofar as he irritated some people with considerations of justice and the pursuit of goodness. His attempts to improve the Athenians' sense of justice may have been the cause of his execution. In 399 BCE, Sokrates went on trial and was subsequently found guilty of both corrupting the minds of the youth of Athens and of impiety ('not believing in the gods of the state'), and as a punishment sentenced to death, caused by the drinking of a mixture containing poison hemlock $[10]$.

When the jury voted about Sokrates' culpability, 280 voted guilty and 220 for acquittal. After this step, the trial entered its penalty stage. Each side was given an occasion to propose a punishment. After listening to arguments, the jurors would choose which of the two suggested punishments to approve. It seems that Sokrates was ready to die because there is little doubt that he was aware that many juries would be offended and insulted by the solution he offered as an alternative penalty:

'Then what do I deserve for such a life? Something good, Athenians, if I am really to propose what I deserve; and something good which it would be suitable to me to receive. Then what is a suitable reward to be given to a poor benefactor, who requires leisure to exhort you? There is no reward, Athenians, so suitable for him as a public maintenance in the Prytaneum, ${ }^{[14]}$.

This is a blatant provocation and also a very bad judicial defense knowing that you have a large part of the jury against. The question then is: why did he do it? I think that perhaps what finally killed him is having tried to cure the blind and paralyzed, but of the mind. But I find that it is contradictory to the fact that Sokrates must have known perfectly well that this was not possible. That is why it is more likely that he concluded that he had already said everything he had to say and decided to avoid the problems of old age. A self-euthanasia. Robin Waterfield suggested that Sokrates was a voluntary scapegoat ${ }^{[15]}$; suggesting that his death was the purifying remedy for Athens's misfortunes. I agree with that of 'voluntary death' but I think he did it also to leave a present and future testimony of the stupidity of his contemporaries. There is no doubt that almost all of his contemporaries did not understand the message. According to Diogenes Laertius, 360 jurors voted for death and 140 for the fine.

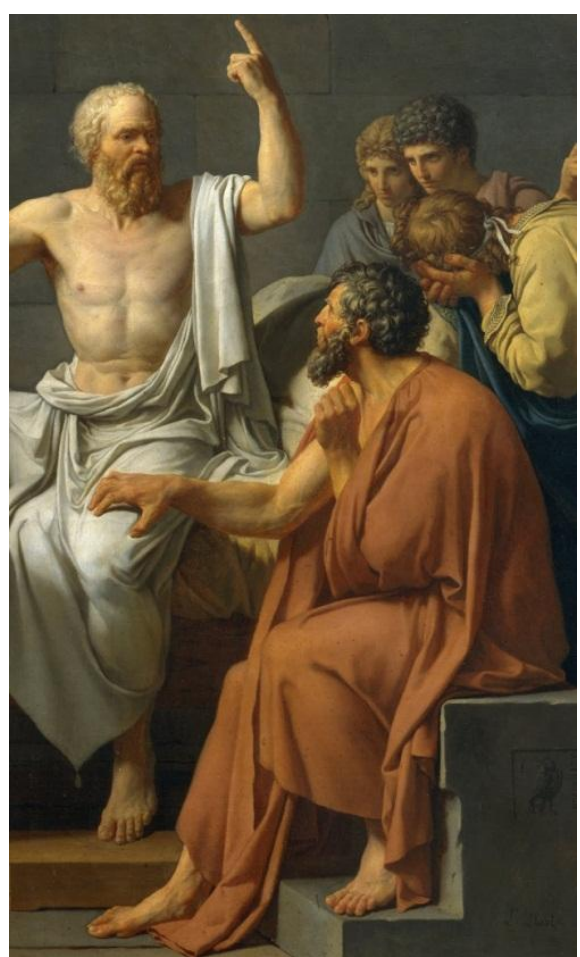

The Death of Sokrates by Jacques Louis David. Crito rests his hand on the thigh of Sokrates.

Physically, Sokrates was very healthy but he has an ugly physiognomy: flat nose, thick lips and prominent eyes, 'like a satyr or Silenus, [16]. Regarding his character, I will mention Aristoxenus' description of Sokrates as 'an ignorant, irascible, sex-driven man who dominates his licentiousness through education while remaining constantly exposed to 
violent emotions' [11]. Perhaps 'Sokrates had an extraordinary power of persuasion, which reflected itself in his voice, his mouth, his manifest character, and his unique outward appearance. But sometimes, when Sokrates was inflamed by anger, his disfigurement was terrible, and he was not able to restrain himself, either in his words or his deeds' [11]. Do not forget that it is usual to clean the biographies of outstanding men, transforming them into quasi-saints.

It is clear that Sokrates did not walk on water, he did not raise the dead or he did not heal blind or paralyzed. Therefore, it seems that we are apparently in presence of a seemingly common Homo sapiens.

\section{THE VeSTIGES OF SOKRATES}

Are there any remnants of what could be Sokrates' authentic thinking? Gregory Vlastos presented the following argument regarding the text of Plato's Apology: 'Plato's Apology has for its mise en scène an all-too-public occasion. The jury alone numbered 500 Athenians. And since the town was so gregarious and Sokrates a notorious public character, there would have been many more in the audience. So when Plato was writing the Apology, he knew that hundreds of those who might read the speech he puts into the mouth of Sokrates had heard the historic original. And since his purpose in writing it was to clear his master's name and to indict his judges, it would have been most inept to make Sokrates talk out of character. How Plato could be saying to his fellow citizens, 'This is the man you murdered. Look at him. Listen to him' and point to a figment of his own imagining? This is my chief reason for accepting the Apology as a reliable recreation of the thought and character of the man Plato knew so well' ${ }^{[17]}$ (I added some corrections). Personally I think that Vlastos is right because there is no doubt that if Plato had included false facts or situations in the Apology, his enemies would have publicly exposed him as a liar. But Vlastos' statement that 'if this is conceded, the problem of our sources is solved in principle' does not seem to be true. It looks like a hasty generalization because there is no solid basis for holding that some of the other writings of Plato present the same Sokrates of the Apology. On the other hand, Xenophon was not in Athens at the time of the trial. He said he founded his Apology on what he was told later by Hermogenes, one of Sokrates' closest pupil ${ }^{[18]}$. Therefore, let us keep Plato's Apology as the most probable and unique Sokratic-like 'text'.

But we must keep in mind Buryeat's important words: 'one day in 399 BCE Sokrates went on trial in Athens, charged with impiety and corrupting the young, and spoke certain words to the jury in his defense. Sometime later-no-one knows how much time later-Plato wrote The Apology of Sokrates, in which Sokrates again speaks certain words to the jury in his defense. No sensible scholar believes that the relation between the first set of words and the second is the relation of identity. It is most unlikely that what Sokrates said and what Plato wrote are exactly the same, if only for the trivial reason that unprepared spoken discourse very seldom comes out as a sequence of syntactically perfect, complete sentences, ${ }^{[19]}$.

\section{THE ORIGIN OF SOKRATES AS A GADFLY}

According to Plato's Apology, Sokrates' life as the 'gadfly' of Athens began when his friend Chaerephon asked the Oracle at Delphi ${ }^{[20-25]}$ if anyone were wiser than Sokrates. The Pythia responded that no one was wiser.

The earliest discoveries in the area of Delphi dated to about 4000 BCE and come from the Korykeion Andron, a cave on Parnassos, where the first rituals took place. As far as we know, Delphi was since ancient times a place of veneration for Gaia (around $1400 \mathrm{BCE}$ ), the mother goddess associated with fertility. Delphi was regarded as being the center of the world.

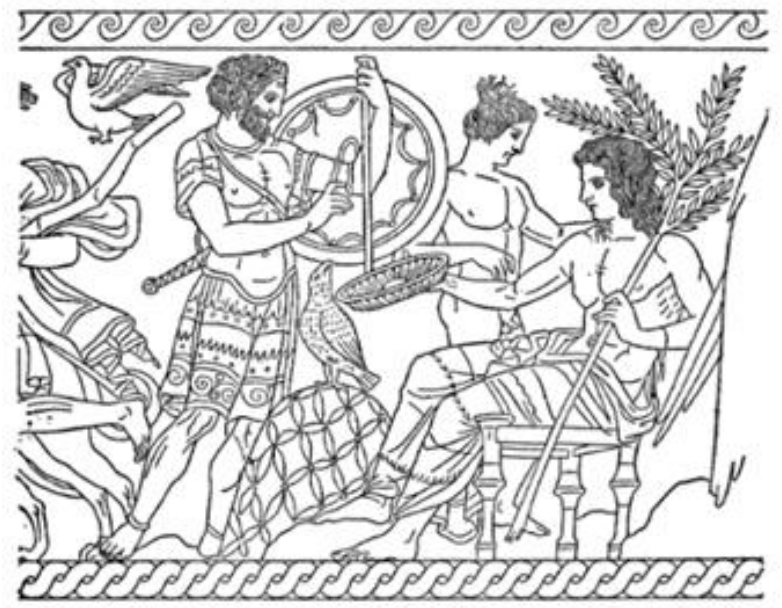

The consultation of Apollo by Oedipus at Delphi ${ }^{[24]}$.

We have no idea how the Pythia 'obtained' the answers to the questions that were consulted. It is true that the Oracle is located on a very special geology but we have no idea what kind of gases could have been emitted during the entire period (more than a thousand years) in which it worked. We do not even know if the composition of the gases varied during that period. That's why it's fun to read polemics in that regard $\stackrel{[26-30]}{ }$. Martin Litchfield West suggested that the Pythia can be seen as a shamaness: 'the Pythia resembles a shamaness at least to the extent that she communicates with her god while in a state of trance, and conveys as much to those present by uttering unintelligible words. It is particularly striking that she sits on a cauldron supported by a tripod. This eccentric perch can hardly be explained except as a symbolic boiling, and, as such, it looks very much like a reminiscence of the initiatory boiling of the shaman translated from hallucinatory experience into concrete visual terms. It was in this same cauldron, probably, that the Titans boiled Dionysus in the version of the story known to Callimachus and Euphorion, and his remains were interred close by' ${ }^{\text {[31] }}$. Given the oldness of Delphi, it would not be strange if the Pythia is only the continuation of a line of 'seers' that is lost in the darkness of the past. Given the geographical origin of the distant ancestors of the Greeks it is plausible to think that they practiced shamanism. What we do not know is whether the form of these practices evolved in, for example, the Pythia (the background does not evolve) [32-34]. This is an interesting topic deserving to be explored. The position of what can be called the 'denial of the oracle of Delphi' could be refuted based on what has been said above 
about the Apology $[\underline{35}, \underline{36}]$.

The matter is that Sokrates believed or showed externally that he believed that the Oracle's response was not correct. It is said that Sokrates began to interrogate many kinds of people to find at least one 'wiser' than him. Vlastos makes the following statement regarding Sokrates tactics to refute the Oracle's declaration: 'Instead of trying to pilot you around the rocks, he picks one under water a long way ahead where you would never suspect it and then makes sure you get all the wind you need to run full-sail into it and smash your keel upon $i t^{,[17]}$. This inevitably causes Vlastos to mention that 'one can't help wondering whether the historical Sokrates could have been really like that ${ }^{\text {'17] }}$. I think he was like that but also that he was not trying to find a man wiser than him. Sokrates had the power of intellectually working on others, generically different from that of any qualified teacher, without parallel either among contemporaries or successors [16]. There are some people stating that Sokrates realized the Oracle was correct. This cannot be true at all because to state this, Sokrates must have questioned all men considered wise by the people of Athens and continued their search traveling to Sparta, Thebes, Miletus, etc., etc., on a journey that has no end. That apparent logical absence of end is what should be the center of attention. It could be that Socrates only used the response of the Pythia as a pretext to teach his pupils a new way of reasoning, all at the cost of questioning allegedly wise men.

\section{MY THESIS}

My Thesis, based on the cylinder-ladder of the previous paper ${ }^{[37]}$, is very simple: Sokrates was on a rung of the ladder that was located much higher than the rungs within segment $A-B$. Let's see what explanatory power this thesis could have.

This man, who is said to have created a new era of thought, many of whose timeless waves still bathe the West, has not left a line behind him. To affirm that, for example, that was because Sokrates was illiterate is nothing more than a sign of mental illiteracy. If he had been illiterate and wished to write something, it would have been enough to ask one of his pupils to transcribe his words. If nothing was written by Sokrates, it is because Sokrates wanted it that way. This is a suggestion that should be explored more. His role as a gadfly in Athens was more important because it was a tool for some of his pupils to broaden his perception of reality.

Moreover, I argue that Sokrates knew that he was relatively wiser than those around him (this statement makes the response of the Pythia even more interesting!), due to its higher location on the cylinder-ladder. What we (or at least I) don't know is how wiser he was. If what I just suggested were true, it would mean that Sokrates was clear that his speech would be interpreted by his listeners according to the place they occupied on the ladder of segment A-B ${ }^{[37]}$. That's why at his death various schools of ancient thought made use of Sokrates, giving origin to Plato and his Academy, Antisthenes and the Cynicism, Aristippus of Cyrene and his Cyrenaic School, Euclides of Megara and his Megarian School and Phaedo of Elis and his Elian School. They were properly called 'imperfect followers' by Zeller ${ }^{[38]}$. He forgot to include Plato, who was one of the most 'imperfect' of all. It is these groups, plus several of their offshoots, that are conventionally known as the 'Socratic schools' [39]. Within this scheme, these two phrases by Vlastos: 'we find a man who is all paradox' and 'the paradox in Sokrates is Sokrates' [17] acquire a new and clearer meaning. From the social point of view, Plato seems to be the best of his pupils. But, from the point of view of broadening the perception of reality, it seems to have been the worst of them.

It is interesting to mention that, almost at the same time but in another geographical place, Siddhārtha Gautama spoke about the Noble Eightfold Path and become the 'Awakened One'.

Regarding a specific problem of the 'Sokratic problem', Bumyeat stated that 'the scholarly literature on this topic is a paradise of inconclusive guesswork' ${ }^{[19]}$. For the reasons exposed above, this paradise will continue existing until all the possibilities, with all their variations and nuances have been explored and published, either in papers or in books $[\underline{8}, \underline{11}$ $\underline{14}, \underline{15}, \underline{17-19}, \underline{39-60]}$. (These are bad news for trees). And on that day we will discover that the advance of our knowledge of Sokrates has not progressed one iota since his death. Only another 'Sokrates' can read Plato, Xenophon and Aristophanes and have the complete vision of what Sokrates really was. I think that the only problem is that this 'Sokrates' will never publish a paper or a book. In summary, Sokrates seems to be the first known Western stonecutter/ stonemason whose raw material is men.

\section{REFERENCES}

[1] D. Fishwick. The Name of the Demigod. Historia: Zeitschrift für Alte Geschichte 1975, 24, 624-628.

[2] H.F. Burton. The Worship of the Roman Emperors. The Biblical World 1912, 40, 80-91.

[3] J.S. Gómez-Jeria. Some remarks about the Graeae (Graiai). World Journal of Research and Review 2017, 4, 42-46, https://doi.org/10.31871/WJRR.4.3.6

[4] R. Hansen; W.F. Hansen. Handbook of classical mythology. Abc-clio: 2004.

[5] J. Lindow. Handbook of Norse mythology. ABC-CLIO: 2001.

[6] G.M. Williams. Handbook of Hindu mythology. Abc-clio: Oxford, England, 2003.

[7] L. Yang; D. An; J.A. Turner. Handbook of Chinese mythology. Abc-clio: Oxford, England, 2005

[8] J.W. Roberts. City of Sokrates: an introduction to classical Athens. Routledge: 2002.

[9] A. Powell. Athens and Sparta: constructing Greek political and social history from 478 BC. Routledge: 2002.

[10] Various. Socrates. https://en.wikipedia.org /wiki/ Socrates (July 7, 2019).

[11] [11] A. Stavru. Aristoxenus on Socrates. In Socrates and the Socratic Dialogue, Brill: Leiden, 2017; pp 623-664.

[12] [12] D. Laertius; C.D. Yonge (Trans.). The lives and opinions of eminent philosophers. H.G. Bohn: London, 1853.

[13] G. Grote. History of Greece. Vol. VI. Harper \& Bros.: New York, 1858.

[14] Plato; F.J. Church. The trial and death of Socrates: being the Euthyphron, Apology, Crito, and Phaedo of Plato.

[15] R. Waterfield. Why Socrates died: dispelling the myths. W. W. Norton \& Co.: New York, 2009.

[16] G. Grote. A history of Greece. Vol. 8. Murray: London, 1851.

[17] G. Vlastos (Ed.). The philosophy of Socrates: A collection of critical essays. In Palgrave Macmillan: 1971.

[18] I.F. Stone. The trial of Socrates. Anchor: New York, 1989.

[19] M.F. Burnyeat. The impiety of Socrates. Ancient Philosophy 1997, 17, 1-12.

[20] M. Dillon. Omens and Oracles: Divination in Ancient Greece. Routledge: 2017

[21] R. Stoneman. The ancient oracles: Making the gods speak. Yale University Press: London, 2011. 
[22] E. Eidinow. Oracles, curses, and risk among the ancient Greeks. Oxford University Press: Oxford, 2007.

[23] H.W. Parke. The Oracles of Zeus: Dodona, Olympia, Ammon. Harvard University Press: Cambridge, 1967.

[24] F.E. Robbins. The lot oracle at Delphi. Classical Philology 1916, 11, 278-292.

[25] H.W. Parke. Chaerephon's Inquiry about Socrates. Classical Philology 1961, 56, 249-250, 10.1086/364620

[26] J.Z. De Boer; J.R. Hale. The geological origins of the oracle at Delphi, Greece. Geological Society, London, Special Publications 2000, 171, 399-412, 10.1144/ gsl.sp.2000.171.01.29

[27] J.Z. De Boer; J.R. Hale; J. Chanton. New evidence for the geological origins of the ancient Delphic oracle (Greece). Geology 2001, 29 , 707-710.

[28] H.A. Spiller; J.R. Hale; J.Z. De Boer. The Delphic oracle: a multidisciplinary defense of the gaseous vent theory. Journal of Toxicology: Clinical Toxicology 2002, 40, 189-196.

[29] J.R. Hale; J.Z. De Boer; J.P. Chanton; H.A. Spiller. Questioning the Delphic oracle. Scientific American 2003, 289, 66-73.

[30] D. Lehoux. Drugs and the Delphic oracle. Classical World 2007, 101, 41-56.

[31] M.L. West. The Orphic Poems. Oxford Univ Press: Oxford, 1983.

[32] J.S. Gómez-Jeria. Biology and Philosophy. III. About Mongrels and How to Shoot down a Crab from a Tree. World Journal of Research and Review 2018, 7, 1-4, 10.31871/wjrr.7.1.23

[33] [33] J.S. Gómez-Jeria. Biology and Philosophy. Part II. The Upper Paleolithic and the Holocene. World Journal of Research and Review 2017, 4, 42-47, 10.31871/WJRR.4.6.7

[34] [34] J.S. Gómez-Jeria. Biology and Philosophy. Part I. The Paleolithic. World Journal of Research and Review 2017, 4, 21-28, 10.31871/WJRR.4.1.14

[35] M. Montuori. Socrates: physiology of a myth. Brill: Layden, 1981.

[36] M. Montuori. The Oracle Given to Chaerephron on the Wisdom of Socrates. An Invention by Plato. Kernos. Revue internationale et pluridisciplinaire de religion grecque antique 1990, 251-259.

[37] J.S. Gómez-Jeria. Biology and Philosophy. VI. Plato "s Cave and Homo sapiens Inequality. World Journal of Research and Review 2019, 8, 23-29, 10.31871/WJRR.8.6.7

[38] E. Zeller; O.J. Reichel (Transl.). Socrates and the Socratic schools. Longmans, Green and Co.: London, 1885.

[39] D.R. Morrison. The Cambridge Companion to Socrates. Cambridge University Press: 2011.

[40] O. Muramoto. Solving the Socratic Problem-A Contribution from Medicine. Mouseion 2018, 15, 445-473, 10.3138/mous.15.3

[41] L. Gerson. The Myth of Plato's Socratic Period. In Archiv für Geschichte der Philosophie, 2014; Vol. 96, pp 403-430.

[42] L. Warren. Towards redefining Socratic irony. Akroterion 2013, 58, $1-17,10.7445 / 58-0-144$

[43] N.C. Rauhut. How Virtuous Was Socrates? In Reason and Analysis in Ancient Greek Philosophy: Essays in Honor of David Keyt, Anagnostopoulos, G.; Miller Jr, F. D., Eds. Springer Netherlands: Dordrecht, 2013; pp 109-123.

[44] L.E.O. Strauss; A. Louis; A. Barrot. Le problème de Socrate. Archives de Philosophie 2007, 70, 289-306.

[45] M. Joyal. To Daimonion and the Socratic Problem. In Apeiron, 2005; Vol. 38, p 97.

[46] C. Osborne. Successors of Socrates, Disciples of Descartes, and Followers of Freud. In Apeiron, 2001; Vol. 34, p 181.

[47] W. Graham Daniel. What Socrates Knew. In Apeiron, 1997; Vol. 30, p 25.

[48] D. Nails. The Socratic Problem. In Agora, Academy, and the Conduct of Philosophy, Nails, D., Ed. Springer Netherlands: Dordrecht, 1995; pp 8-31.

[49] G. VIastos. Is the 'Socratic Fallacy'Socratic? Ancient Philosophy 1990, 10, 1-16.

[50] P.W. Gooch. Socrates: Devious or Divine? Greece and Rome 1985, 32, 32-41, 10.1017/s0017383500030114.

[51] R. Eisner. Socrates as hero. Philosophy and Literature 1982, 6, 106-118.

[52] A.R. Lacey. Our Knowledge of Socrates. In The Philosophy of Socrates: A Collection of Critical Essays, Vlastos, G., Ed. Palgrave Macmillan: London, 1971; pp 22-49.

[53] C.J. de Vogel. The Present State of the Socratic Problem. Phronesis 1955, 1, 26-35.

[54] J. Patočka. Remarques sur le problème de Socrate. Revue Philosophique de la France et de l'Étranger 1949, 139, 186-213.

[55] E.A. Havelock. The Evidence for the Teaching of Socrates. Transactions and Proceedings of the American Philological Association 1934, 65, 282-295, 10.2307/ 283034.
[56] H.H. Dubs. The Socratic Problem. The Philosophical Review 1927, 36, 287-306, 10.2307/2179240.

[57] L. Judson; V. Karasmanis. Remembering Socrates: philosophical essays. Clarendon Press: Oxford, 2006.

[58] G. Xenophon Santas. Socrates. The arguments of the Philosophers. Routledge: London, 1999.

[59] M.F. Burnyeat; J. Barnes. Socrates and the jury: Paradoxes in Plato's distinction between knowledge and true belief. Proceedings of the Aristotelian Society, Supplementary Volumes 1980, 54, 173-206.

[60] J. Hintikka. Socratic epistemology: Explorations of knowledge-seeking by questioning. Cambridge University Press: Cambridge, 2007.

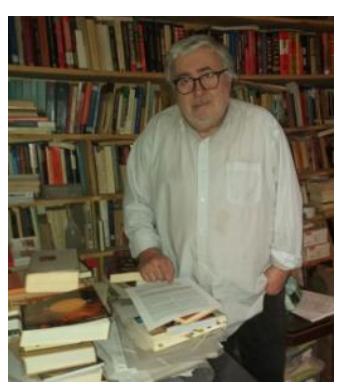

Juan Sebastián Gómez-Jeria. Graduate in Chemistry and Chemist at the University of Chile, $\mathrm{PhD}$ in Molecular Physical Chemistry. Research in Quantitative Structure-Activity relationships, electronic structure of nanostructures and philosophy of science. Lecturer in Quantum Chemistry and Quantum Pharmacology and History and Philosophy of Science. He has published three books and more than 180 papers. He is preparing the book Biology and Philosophy. 